\title{
Development and evaluation of 16 new microsatellite loci for the rock ptarmigan (Lagopus muta) and cross-species amplification for the willow grouse (L. lagopus)
}

\author{
Jean-Marc Costanzi ${ }^{*} \mathbb{0}$, Frode Bergan, Mona Sæbø, Andrew Jenkins and Øyvind Steifetten
}

\begin{abstract}
Objective
Abstract: The genetic markers designed for this study can facilitate future genetic studies on the rock ptarmigan (Lagopus muta). To our knowledge no microsatellite markers have ever been developed specifically for this species before. These new microsatellite markers will be useful for population genetics studies and for future conservation projects.

Results: Using Next Generation Sequencing 6252 potential microsatellite sequences were found. Sixteen nonpalindromic tetranucleotide microsatellites and their respective primers were selected. The markers were tested on both the rock ptarmigan and the willow grouse (L. lagopus). The number of alleles varied between 2 and 18 for the rock ptarmigan, and between 3 and 13 for the willow grouse. Expected heterozygosity was in the range 0.1244-0.8692 and $0.1358-0.8722$ for the rock ptarmigan and the willow grouse, respectively.
\end{abstract}

Keywords: Birds, Lagopus muta, Lagopus lagopus, Microsatellites, Population genetics

\section{Introduction}

The rock ptarmigan (Lagopus muta) and the willow grouse (L. lagopus) are two closely related bird species that inhabit the alpine zone throughout the northern hemisphere. In Scandinavia they are important game species. Both have experienced a drastic decline in recent years [1] and there is an urgent need for tools to investigate the underlying causes of the decline, including markers for population genetic studies. To our knowledge only two studies on population genetics have been carried out on the rock ptarmigan, but none of the markers used were species-specific $[2,3]$.

Microsatellite markers have many applications [4], and with only a limited number of markers needed, they are among the most popular type of genetic markers used in ecological studies [5]. Although single-nucleotide

\footnotetext{
*Correspondence: jean-marc.costanzi@usn.no

Department of Natural Sciences and Environmental Health, University College of Southeast Norway, Gullbringvegen 36, 3800 Bø i Telemark, Norway
}

polymorphisms (SNPs) are becoming increasingly popular for population genetic studies, due to the ease with which they can be read, microsatellites still have some advantages [5]. Microsatellite markers are more polymorphic than SNPs [6], so a smaller number of loci is needed for the same level of precision [7], decreasing the cost of the analysis. Moreover some studies suggest that microsatellite markers are better than SNPs to detect recent population structure events $[8,9]$. However, in order to prevent high scoring error rates, only long motifs (tetranucleotides), which are less subject to slippage, should be selected [10]. This also aids inter-laboratory comparison.

To avoid the problem of null alleles, polymerase chain reaction (PCR) based markers require primer sequences that bind to highly conserved regions with few or no inter-individual differences. To minimize errors due to primer site mutations it is best to use species-specific markers [11].

The number of markers required is inversely correlated with the degree of genetic differentiation across 
populations. Thus, for large populations or species with a high migration rate (as is the case for the rock ptarmigan), a larger number of microsatellites is required [4]. In this study, we have designed microsatellite markers specifically for the rock ptarmigan and also tested their potential with the closely-related willow grouse.

\section{Main text}

\section{Materials and methods}

For the library construction approximatively $1 \mathrm{mg}$ of ethanol-preserved liver sample from a rock ptarmigan originating from the western part of the Hardangervidda plateau, Norway, was used. This was sent to Cornell University (Ithaca, New York, USA), where the following analyses were conducted as a commercial service. At the Evolutionary Genetics Core Facility a library was prepared; this was then sent to the Sequencing and Genotyping Facility (Cornell Life Sciences Core Laboratory Center) for Titanium 454 sequencing. The sequences obtained were assembled under stringent condition with a match size of 120 base pair (bp), a match percentage of $94 \%$ and a minimum sequence length of $150 \mathrm{bp}$. From this dataset all di-, tri-, tetra-, penta- and hexanucleotides repeats were screened with the software msatcommander [12,13] and sequences less than $100 \mathrm{bp}$ and/or with a small number of repeats were excluded. Primers were designed with Primerselect software (part of the Lasergene package [14]). Every microsatellite sequence chosen was run through the online version of the Basic Local Alignment Search Tool for nucleotide (BLASTn) [15] in order to check for similarity with already published sequences.

To examine whether the selected microsatellites exhibited enough polymorphism, additional rock ptarmigan samples were collected from two distinct areas $324 \mathrm{~km}$ apart (Table 1). DNA from tested populations came from feathers (from hunted birds), and from fecal pellets found on the ground [16].

DNA extraction, PCR and genotyping of the tested populations was done at the genetic laboratory of the University College of Southeast Norway. Two different DNA extraction kits were used depending on the type of sample; the "DNeasy Blood \& Tissue kit" (Qiagen, Cat. No. 69506) for feathers, and the "QIAamp DNA Stool
Mini Kit" (Qiagen, Cat. No. 51504) for fecal pellets. In order to increase the quantity of DNA extracted during the "DNeasy Blood \& Tissue" procedure, $5 \mu \mathrm{L}$ of DTT $1 \mathrm{M}$ was added to the ATL buffer during the first step of the protocol. In the "QIAamp DNA Stool Mini Kit" protocol, the quantity of buffer ASL was increased from 1.4 to $1.6 \mathrm{~mL}$. In order to assess the efficiency of DNA extraction, the concentration of DNA was measured with a Qubit ${ }^{\mathrm{TM}}$ dsDNA HS Assay kit (Thermo Scientific ${ }^{\mathrm{TM}}$ Cat. No. Q32854) on a Qubit 3.0 Fluorometer (Thermo Scientific $^{\mathrm{TM}}$ ) for 30 samples. Each sample was amplified with species-specific mitochondrial DNA primers Lagsp3F, Lag3R and Mut3R [see 17] in order to distinguish L. muta and L. lagopus, whose fecal pellets are not distinguishable morphologically, and whose habitats overlap. PCR conditions follow Nyström et al. 2006 [17], and the results were read via gel electrophoresis [16]. Rock ptarmigans were identified by an amplicon size of $212 \mathrm{bp}$, and willow grouse by an amplicon size of $154 \mathrm{bp}$.

For microsatellite analysis, PCR amplification was performed with forward primers labeled with FAM NED, PET or VIC fluorescent dyes. The reaction was made with $6 \mu \mathrm{L}$ of "Qiagen Taq PCR mastermix" (Qiagen, Cat. No. 201445) with a final concentration of $1 \times, 0.25 \mu \mathrm{L}$ of a $20 \mu \mathrm{M}$ stock of each primers, $2 \mu \mathrm{L}$ of DNA template and ultrapure water to a total volume of $12 \mu \mathrm{L}$. PCR was done in an Eppendorf Mastercycler ${ }^{\circledR}$ gradient thermal cycler: $15 \mathrm{~min}$ at $95{ }^{\circ} \mathrm{C}, 40$ cycles consisting of $30 \mathrm{~s}$ at $94{ }^{\circ} \mathrm{C}$, $90 \mathrm{~s}$ at $60{ }^{\circ} \mathrm{C}, 60 \mathrm{~s}$ at $72{ }^{\circ} \mathrm{C}$, and finally $10 \mathrm{~min}$ at $72{ }^{\circ} \mathrm{C}$. Microsatellite markers were multiplexed in five different PCR reactions. For every reaction a negative control was included and analysed in parallel with the samples. If any positive signal was found in the negative control the results were rejected and the entire run was repeated. In order to check for consistency of the data, 28 rock ptarmigan samples were tested twice.

For the genotyping $1.5 \mu \mathrm{L}$ of PCR product was added in a mix containing $9.7 \mu \mathrm{L}$ of formamide (Thermo Scientific $^{\mathrm{TM}}$, Cat. No. 17899) and $0.3 \mu \mathrm{L}$ of GeneScan 500LIZ dye Size Standard (Applied Biosystems ${ }^{\mathrm{TM}}$, Cat. No. 4322682). Genotyping was realized on a 3130xl Genetic analyzer (Applied Biosystems). Allele scoring was done using GeneMapper software V5.0 and visually controlled (Applied Biosystems). To avoid analyzing the same

Table 1 Summary of the genetic samples collected in southern Norway and in Sweden during 2015/16

\begin{tabular}{lllllll}
\hline Site & Species & No. individuals & Fecal pellets & Feathers & Latitude & Longitude \\
\hline Bykle (Norway) & Rock ptarmigan & 32 & 6 & 26 & $59^{\circ} 25^{\prime} 23.95^{\prime \prime}$ & $7^{\circ} 3^{\prime} 50.49^{\prime \prime}$ \\
Lesja (Norway) & Rock ptarmigan & 31 & NA & 31 & $62^{\circ} 10^{\prime} 22.55^{\prime \prime}$ & $9^{\circ} 0^{\prime} 9.55^{\prime \prime}$ \\
Ringebu (Norway) & Willow grouse & 21 & 21 & NA & $61^{\circ} 34^{\prime} 21.27^{\prime \prime}$ & $10^{\circ} 20^{\prime} 9.74^{\prime \prime}$ \\
Fulufället (Sweden) & Willow grouse & 22 & 22 & NA & $61^{\circ} 29^{\prime} 15.86^{\prime \prime}$ & $12^{\circ} 40^{\prime} 31.51^{\prime \prime}$ \\
\hline
\end{tabular}


individual twice, an individual identity analysis was carried out with the software Cervus V3.0.7 [18]. The minimum number of matching loci was set to 7 , and 1 fuzzy matching was allowed. Microsatellite markers were then tested for the presence of null alleles with the software microchecker [19]. Linkage disequilibrium and HardyWeinberg equilibrium were tested with the software GENEPOP [20]. In order to control for multiple testing, the $p$ value threshold was adjusted with Bonferroni correction. Number of alleles $\mathrm{Na}$, observed heterozygosity
$H_{\mathrm{o}}$ and expected heterozygosity $H_{\mathrm{e}}$ were calculated with the software Genetix V4.05 [21, see Table 2]. The same procedures were also performed on samples from the willow grouse, which were collected from two different areas $124 \mathrm{~km}$ apart in Norway and in Sweden (Table 1).

\section{Results}

After the Titanium 454 sequencing 31037 sequences were obtained, which resulted in 6252 potential microsatellite sequences after screening with msatcommander. Sixteen

Table 2 Characterization of 16 polymorphic microsatellites for the rock ptarmigan (regular font) and the willow grouse (italics)

\begin{tabular}{|c|c|c|c|c|c|c|c|c|}
\hline Locus name & $\begin{array}{l}\text { Repeat motif } \\
\text { of cloned } \\
\text { allele }\end{array}$ & $\begin{array}{l}\text { GenBank } \\
\text { accession } \\
\text { number }\end{array}$ & Primer sequence $\left(5^{\prime}-3^{\prime}\right)$ & Primer dye & $\begin{array}{l}\text { Allele size } \\
\text { range (bp) }\end{array}$ & $\mathrm{Na}$ & $H_{\mathrm{E}}$ & $H_{\mathrm{O}}$ \\
\hline \multirow[t]{2}{*}{ Mut01 } & (ATCC)8 & MF425753 & F: GGTCACTTGTGGCTATTAGAACC & PET & $85-104$ & 6 & 0.6545 & $0.6129[0.0016]^{* *}$ \\
\hline & & & R: CTGAGAAAGACAATGGTGGATGG & & $85-115$ & 8 & 0.7361 & $0.6667[0.0606]$ \\
\hline \multirow[t]{2}{*}{ Mut02 } & $($ ATCC) 9 & MF425754 & F: GATGGATGAACAGACAGTGGATG & FAM & $99-127$ & 8 & 0.6454 & $0.6984[0.7326]$ \\
\hline & & & R: CACTCACTTGCTTATATGATTCCC & & $103-127$ & 6 & 0.7243 & $0.5366[0.0001]^{* * *}$ \\
\hline \multirow[t]{2}{*}{ Mut03 } & $(\mathrm{AAAC}) 7$ & MF425755 & F:TCACTAAATCATGGAAAGCAATGG & NED & $100-116$ & 5 & 0.6925 & $0.7069[0.8376]$ \\
\hline & & & R: GGTGAGGTGGATTATCATATGCAG & & $N A$ & NA & $N A$ & $N A$ \\
\hline \multirow[t]{2}{*}{ Mut04 } & (ATCC) 11 & MF425756 & F: AACATGGTCCTACACTTCAGAGG & VIC & $107-131$ & 6 & 0.7602 & $0.8571[0.9064]$ \\
\hline & & & R: ATGTACACAAGGAAGCATTCAGG & & $115-151$ & 8 & 0.8324 & $0.8421[0.2652]$ \\
\hline \multirow[t]{2}{*}{ Mut06 } & $(A A A C) 7$ & MF425757 & F:TTGAACACTAATCTCGCCATTGC & PET & $110-130$ & 6 & 0.6983 & $0.6984[0.5816]$ \\
\hline & & & R: GTGGGATATGAGGAAAGAGTTGC & & $114-126$ & 4 & 0.5541 & $0.2093[0.0001]^{* * *}$ \\
\hline \multirow[t]{2}{*}{ Mut08 } & $(A A G C) 6$ & MF425758 & F:TACTACTTTCTGAACTCTGCTGC & VIC & $122-176$ & 9 & 0.8332 & $0.7705[0.0032]^{*}$ \\
\hline & & & R: GAGAGAAGAAGGAACAAACAAGC & & $122-201$ & 11 & 0.8722 & $0.7105[0.0037]^{*}$ \\
\hline \multirow[t]{2}{*}{ Mut09 } & $(\mathrm{AGAT}) 10$ & MF425759 & F: CACTCTAGTTCAACCTGTTCAGC & VIC & $125-161$ & 8 & 0.8083 & $0.7931[0.3421]$ \\
\hline & & & R: CTCTTAGAGAATTTGCTGCTGTG & & $125-153$ & 8 & 0.8072 & $0.4250[0.0000]^{* * *}$ \\
\hline \multirow[t]{2}{*}{ Mut12 } & $(\mathrm{AAAC}) 6$ & MF425760 & F: GGAAGGAGCTTACACATAGGAAC & NED & $123-150$ & 7 & 0.7448 & $0.5932[0.0000]^{* *}$ \\
\hline & & & R: GGAGGATCTTGTACTTGCAGTTG & & $146-154$ & 6 & 0.5971 & $0.5814[0.4043]$ \\
\hline \multirow[t]{2}{*}{ Mut14 } & $(\mathrm{AAAC}) 5$ & MF425761 & F:TCTGCCAACTTCTTTATGCTGTC & FAM & $154-174$ & 6 & 0.6596 & $0.6825[0.4565]$ \\
\hline & & & R:TTCTTTCAATTCATTAGCCCAGTG & & $148-160$ & 4 & 0.1358 & $0.0952[0.0478]^{*}$ \\
\hline \multirow[t]{2}{*}{ Mut16 } & (AGAT)12 & MF425762 & F:TGCTGTAATTGGCTAGTGGTTTC & NED & $155-171$ & 5 & 0.6658 & $0.6452[0.4086]$ \\
\hline & & & R: CGGTCAGGTGTTTCTCAGTAAAG & & $151-183$ & 9 & 0.8164 & $0.7209[0.0275]^{*}$ \\
\hline \multirow[t]{2}{*}{ Mut17 } & $(\mathrm{AAAG}) 15$ & MF425763 & F: CCAAGAACACAGAAATCCCAGAG & PET & $134-226$ & 18 & 0.7586 & $0.6207[0.0105]^{*}$ \\
\hline & & & R:TGTTAATTGACTGCCACAAACTAC & & $126-174$ & 5 & 0.4207 & $0.3514[0.1756]$ \\
\hline \multirow[t]{2}{*}{ Mut18 } & $(A A A C) 6$ & MF425764 & F:TTCACTCATAACTAAGCAAAGCAG & FAM & $171-183$ & 4 & 0.6122 & $0.5690[0.0747]$ \\
\hline & & & R:TGCATTGGAATTACTGTTGATGC & & $178-183$ & 3 & 0.4436 & $0.4048[0.3302]$ \\
\hline \multirow[t]{2}{*}{ Mut20 } & $($ ATCC) 13 & MF425765 & F: CTTTCCACCTTTCTTACTGCCTG & PET & $173-213$ & 11 & 0.8692 & $0.7500[0.0068]^{*}$ \\
\hline & & & R: CTCATCCTGTATTTCTGAGCTGC & & $157-217$ & 13 & 0.8430 & $0.7143[0.0344]^{*}$ \\
\hline \multirow[t]{2}{*}{ Mut22 } & $(A A A C) 6$ & MF425766 & F: GTGGTATCTCTGTAACTTGGGAG & FAM & 179-195 & 3 & 0.4259 & $0.4444[0.6885]$ \\
\hline & & & R: AAGGCAAAGCAAGAATGTCTGTG & & 179-191 & 4 & 0.6684 & $0.6098[0.2344]$ \\
\hline \multirow[t]{2}{*}{ Mut23 } & $(\mathrm{AGAT}) 9$ & MF425767 & F: CTGGAGTCTAGAATTGCCACAAC & NED & $173-209$ & 10 & 0.8206 & $0.7833[0.1645]$ \\
\hline & & & R: AGGGTCAAGAACTTACAATGGAC & & $173-197$ & 7 & 0.7064 & $0.7027[0.3735]$ \\
\hline \multirow[t]{2}{*}{ Mut24 } & $(\mathrm{AAAG}) 5$ & MF425768 & F: AACTGACAATCAAGCATCTCATG & PET & 198-202 & 2 & 0.1244 & $0.1333[1.0000]$ \\
\hline & & & R: CTGCTATGTACTACTCAAGGTGC & & $N A$ & $N A$ & NA & $N A$ \\
\hline
\end{tabular}

NA, no available data for the species; $N a$, number of observed alleles; $H_{\mathrm{O}}$, observed heterozygosity; $H_{\mathrm{E}}$, expected heterozygosity

Brackets: $p$ values for the exact tests of departure from Hardy-Weinberg proportions ( $\mathrm{H} 1$ heterozygosity deficit)

${ }^{*} \mathrm{p}<0.05,{ }^{* *} \mathrm{p}<0.0031$ (Bonferroni correction for the rock ptarmigan), ${ }^{* *} \mathrm{p}<0.0033$ (Bonferroni correction for the willow grouse) 
microsatellite nonpalindromic tetranucleotide repeats with lengths between 85 and $226 \mathrm{bp}$, and with number of repeats between 5 and 15 were selected. BLASTn analysis of the sequences gave two positive matches with red jungelfowl (Gallus gallus) sequences. The first sequence named CH261-100D18 (Accession Number AC147597) had an $87 \%$ match with Mut18, but the repeat motif was not present on the Gallus galllus sequence. The second sequence named 8F6 (Accession Number X78623.1 [22]), had a $90 \%$ match with Mut01 and the repeat motif was identical. Because we couldn't find any publications using this microsatellite on grouse, we kept it for analysis.

In total 63 rock ptarmigan individuals were tested (Table 1). Measured DNA quantity for the 30 samples tested ranged from 0.06 to $44 \mathrm{ng} / \mu \mathrm{L}$ (average: $7 \mathrm{ng} / \mu \mathrm{L}$ ). Identity analysis with Cervus detected three redundant individuals that were removed prior to analysis. Replicate data was available for 28 rock ptarmigan samples, representing a total of 371 pairs of allele identification (failed reaction were not counted). There was in total nine mismatches between replicates, one mismatch for Mut18, Mut4 and Mut22, two mismatches for Mut12 and three mismatches for Mut20. The software microchecker detected one microsatellite marker (Mut12) that presented a high frequency of null alleles. No significant linkage disequilibrium was found after Bonferronicorrection. A significant deviation $(\mathrm{p}<0.0031)$ from Hardy-Weinberg (heterozygosity deficit) was found after Bonferroni correction on markers Mut01 and Mut12. The total number of alleles per microsatellite ranged from 2 (Mut24) to 18 (Mut17). Expected heterozygosity was between 0.1244 (Mut24) and 0.8332 (Mut08), and observed heterozygosity ranged between 0.1333 (Mut24) and 0.8571 (Mut04) (Table 2).

For the willow grouse the microsatellite markers Mut03 and Mut24 were hard to read and therefore removed from analysis, but the other microsatellites produced amplicon of size and pattern equivalent to the rock ptarmigan. Two microsatellite markers, Mut06 and Mut09, presented a high frequency of null alleles. No significant linkage disequilibrium was found after Bonferronicorrection. A significant deviation $(\mathrm{p}<0.0033)$ from Hardy-Weinberg (heterozygosity deficit) was found after Bonferroni correction for markers Mut02, Mut06 and Mut09. The total number of alleles per microsatellite for the willow grouse ranged from 3 (Mut18) to 13 (Mut20), expected heterozygosity from 0.1358 (Mut14) to 0.8722 (Mut08), and observed heterozygosity from 0.0952 (Mut14) to 0.8421 (Mut04).

\section{Discussion}

Most of the tested microsatellite markers produced good results, except for Mut01 and Mut12, which both presented a heterozygosity deficit. The heterozygosity deficit of Mut01 could be explained by the Wahlund-effect [23], as we pooled two different populations together for the Hardy-Weinberg equilibrium calculation. When calculating heterozygosity deficit separately for each of the two populations, only Mut12 presented a significant heterozygosity deficit after Bonferroni correction. The significant heterozygosity deficit for Mut12 is probably due to the presence of null alleles.

The need for high quality and species-specific microsatellite markers resulted in the development of a new library for the rock ptarmigan. The microsatellites have primers optimised for the target species and are designed to have a low amount of stutter, by selecting tetranucleotide repeat motifs, which are significantly less prone to slippage and a repeat number of five in order to achieve high degrees of polymorphism and heterozygosity, [24]. The high level of heterozygosity and the important number of alleles makes them suitable for studies on population structure and/or dispersal behaviour.

\section{Limitations}

- The number of published microsatellite markers could be too low for population structure analysis at a local scale.

- While tetranucleotide motif are less prone to slippage, they are also less polymorphic than di- or trinucleotide motif.

- These microsatellite markers have only been tested on two species of grouse.

\section{Abbreviations}

PCR: polymerase chain reaction; bp: base pair; BLASTn: Basic Local Alignment Search Tool for nucleotide; $N a$ : number of alleles; $\mathrm{H}_{\mathrm{o}}$ : observed heterozygosity; $\mathrm{H}_{\mathrm{e}}$ : expected heterozygosity.

\section{Author's contributions}

$\varnothing S$ originated with the project idea, supervised the project and secured the funding. MS developed the study design and the methods. FB, collected and prepared the sample for the library construction and sequencing. FB and JMC did the sample collection. FB selected the microsatellite loci and developed the primers. AJ participated in the study design, selection of the microsatellite loci and the primers developments. FB and JMC did the laboratory work for the genotyping. JMC did the data analysis and the writing of the manuscript. All authors, participated in the draft. All authors read and approved the final manuscript.

\section{Acknowledgements}

We would like to thank Pauline Casters, Sylvain Clot, Richard Hančinský, Inger Marie Hernes, Zuzana Krajova, Iver Lodden Boine, Damien Picard, Tereza Prikrylova, Christian Robstad, Johanna Skrutvold, Juraj Sovcik and Michal Torma for assistance in the field, and Martin Hagen Ring for helping out in the field and in the laboratory. Finally, we would like to thank all the hunters that sent us feather samples.

Competing interests

The authors declare that they have no competing interests. 


\section{Availability of data and materials}

The 6252 potential microsatellite sequences that were screened, their respective primers, and the 31037 raw sequences obtained from the Titanium 454 sequencing are available on demand to the corresponding author. Genotype data for every individual and microsatellite loci are also available on demand to the corresponding author.

\section{Consent for publication}

Not applicable.

\section{Ethics approval and consent to participate}

Not applicable.

\section{Funding}

The study was funded by the University College of Southeast Norway.

\section{Publisher's Note}

Springer Nature remains neutral with regard to jurisdictional claims in published maps and institutional affiliations.

Received: 20 December 2017 Accepted: 12 February 2018

Published online: 20 February 2018

\section{References}

1. Henriksen S, Hilmo O. Norsk rødliste for arter 2015. Norge: Artsdatabanken; 2015. p. 193.

2. Caizergues A, Bernard-Laurent A, Brenot J-F, Ellison L, Rasplus JY. Population genetic structure of rock ptarmigan Lagopus mutus in Northern and Western Europe. Mol Ecol. 2003;12:2267-74. https://doi.org/10.1046/ j.1365-294X.2003.01889.x.

3. Bech N, Boissier J, Drovetski S, Novoa C. Population genetic structure of rock ptarmigan in the 'sky islands' of French Pyrenees: implications for conservation. Anim Conserv. 2009;12:138-46. https://doi.org/10.111 1/j.1469-1795.2008.00233.x

4. Selkoe KA, Toonen RJ. Microsatellites for ecologists: a practical guide to using and evaluating microsatellite markers. Ecol Lett. 2006;9:615-29. https://doi.org/10.1111/j.1461-0248.2006.00889.x

5. Guichoux E, Lagache L, Wagner S, Chaumeil P, Léger $P$, Lepais $O$, et al. Current trends in microsatellite genotyping. Mol Ecol Resour. 2011;11:591611. https://doi.org/10.1111/j.1755-0998.2011.03014x.

6. Fabbri E, Caniglia R, Mucci N, Thomsen HP, Krag K, Pertoldi C, et al. Comparison of single nucleotide polymorphisms and microsatellites in non-invasive genetic monitoring of a wolf population. Arch of Biol Sci. 2012:64:321-35. https://doi.org/10.2298/abs1201321f.

7. Gärke C, Ytournel F, Bed'hom B, Gut I, Lathrop M, Weigend S, et al. Comparison of SNPs and microsatellites for assessing the genetic structure of chicken populations. Anim Genet. 2012;43:419-28. https://doi.org/10.111 1/j.1365-2052.2011.02284.x.

8. DeFaveri J, Viitaniemi H, Leder E, Merila J. Characterizing genic and nongenic molecular markers: comparison of microsatellites and SNPs. Mol Ecol Resour. 2013;13:377-92. https://doi.org/10.1111/1755-0998.12071.
9. Granevitze Z, David L, Twito T, Weigend S, Feldman M, Hillel J. Phylogenetic resolution power of microsatellites and various single-nucleotide polymorphism types assessed in 10 divergent chicken populations. Anim Genet. 2014;45:87-95. https://doi.org/10.1111/age.12088.

10. Flores-Renteria L, Whipple AV. A new approach to improve the scoring of mononucleotide microsatellite loci. Am J Bot. 2011;98:e51-3. https://doi. org/10.3732/ajb.1000428.

11. Glenn TC, Schable NA. Isolating microsatelite DNA Loci. Methods Enzymol. 2005:395:202-22. https://doi.org/10.1016/S0076-6879(05)95013-1.

12. Faircloth BC. Msatcommander: detection of microsatellite repeat arrays and automated, locus-specific primer design. Mol Ecol Resour. 2008:8:92-4.

13. Rozen S, Skaletsky H. Primer3 on the WWW for general users and for biologist programmers. In: Misener S, Krawetz SA, editors. Methods in molecular biology. Totowa, NJ: Humana Press; 2000. p. 365-386.

14. DNASTAR. Lasergene package. https://www.dnastar.com/t-dnastar-laser gene.aspx. Accessed 25 Sept 2017

15. NCBI. Basic Local Alignment Search Tool. https://blast.ncbi.nlm.nih.gov/. Accessed 20 Sept 2017

16. Bergan F, Sæbø M, Parker H. Evaluation of in-field stability of mitochondrial and nuclear DNA in snow sampled fecal pellets from Rock ptarmigan (Lagopus muta). Oecol Mont. 2016;25:1-14.

17. Nyström J, Dalén L, Hellström P, Ekenstedt J, Angleby H, Angerbjörn A Effect of local prey availability on gyrfalcon diet: DNA analysis on ptarmigan remains at nest sites. J Zool. 2006;269:57-64. https://doi.org/10.111 1/j.1469-7998.2006.00050.x

18. Kalinowski ST, Taper ML, Marshall TC. Revising how the computer program cervus accommodates genotyping error increases success in paternity assignment. Mol Ecol. 2007;16:1099-106. https://doi. org/10.1111/j.1365-294X.2007.03089.X

19. Van Oosterhout $C$, Hutchinson WF, Wills DPM, Shipley P. micro-checker: software for identifying and correcting genotyping errors in microsatellite data. Mol Ecol Notes. 2004;4:535-8. https://doi.org/10.111 1/j.1471-8286.2004.00684.x

20. Raymond M, Rousset F. GENEPOP (Version 1.2): population genetics software for exact tests and ecumenicism. J Hered. 1995:86:248-9.

21. Belkhir K, Borsa P, Chikhi L, Raufaste F, Bonhomme N. GENETIX 4.05, logiciel sous Windows TM pour la génétique des populations. Montpellier: Laboratoire Génome, Populations, Interactions, CNRS UMR 5171, Université de Montpellier Il; 2004.

22. Gibbs M, Dawson DA, McCamley C, Wardle AF, Armour JA, Burke T. Chicken microsatellite markers isolated from libraries enriched for simple tandem repeats. Anim Genet. 1997;28:401-17. https://doi.org/10.111 1/j.1365-2052.1997.00184.x.

23. Allendorf FW, Luikart G. Conservation and the Genetics of Populations. Hoboken: Blackwell Publishing; 2007. p. 664.

24. Edwards A, Civitello A, Hammond HA, Caskey CT. DNA typing and genetic mapping with trimeric and tetrameric tandem repeats. Am J Hum Genet. 1991:49:746-56.

\section{Submit your next manuscript to BioMed Central} and we will help you at every step:

- We accept pre-submission inquiries

- Our selector tool helps you to find the most relevant journal

- We provide round the clock customer support

- Convenient online submission

- Thorough peer review

- Inclusion in PubMed and all major indexing services

- Maximum visibility for your research

Submit your manuscript at www.biomedcentral com/submit
Ciomed Central 